\title{
The Aesthetic Appreciation of Nature in School Science Education: How Science Learning Can Help Raise Environmental Awareness
}

\author{
Yannis Hadzigeorgiou, Mary Kampouropoulou, Persa Fokiali \\ School of Humanities, University of the Aegean, Rhodes, Greece \\ Email: hadzigeo@rhodes.aegean.gr
}

Received 20 March 2015; accepted 16 May 2015; published 19 May 2015

Copyright @ 2015 by authors and Scientific Research Publishing Inc.

This work is licensed under the Creative Commons Attribution International License (CC BY). http://creativecommons.org/licenses/by/4.0/

(c) (i) Open Access

\section{Abstract}

This paper focuses upon the problem of raising environmental awareness in the context of school science education through an aesthetic appreciation of natural phenomena. In distinguishing between school learning and what could be called "conscious learning", the paper explores the role that such an aesthetic appreciation of nature, and more specifically of natural entities, such as trees, laves, water drops, crystals, and phenomena, such as, flashes of lightning, aurora borealis, the water cycle, volcanic eruptions and stellar explosions, can be an integral part of science teaching, which, in turn, can help raise in students environmental awareness.

\section{Keywords}

Environmental Awareness, Environmental Education, School Science, Aesthetics, Aesthetic Appreciation, Wonder

\section{Introduction}

Over the last two decades there has been a discussion about what could be called the aesthetic dimension of science (Fisher, 1999; Root-Bernstein, 1996, 2002; Tauber, 1996). The view that the boundaries between science and art are blurred, and that science and art share a common aesthetic element is in line with recent developments in the area of the philosophy of science. More specifically, such a view is in line with the shift from a positivist philosophy to a philosophy, which recognizes the centrality of one's personal beliefs, convictions, and even aesthetic considerations in scientific inquiry and in the process of knowledge acquisition in general 
(Hadzigeorgiou, 2005). Kuhn (1970) has pointed out that aesthetic considerations did play, not just a significant, but a decisive role in the adoption of a new paradigm. Thus it makes real sense to include art and science connections in the curriculum. But what if environmental awareness is an educational goal, whose achievement depends upon the contribution all curriculum subjects make, including science? Can science, aesthetics, and environmental awareness co-exist in a curriculum?

Science, of course, is a subject, which can offer several opportunities for fostering environmental awareness (Littledyke, 1996, 2008). Notwithstanding the limitations and the problems inherent in teaching environmental issues in the context of science education (see Hadzigeorgiou \& Skoumios, 2013), one has to acknowledge the fact that the STS (Science, Technology, Society) movement in science education helped pave the way toward the inclusion of social issues and problems in the science curriculum. And the pedagogical advantages resulting from such inclusion (i.e., issues/problems can provide a context for learning, can provide students with a purpose, can discourage a "spectator theory" of knowledge, can facilitate the development of planetary consciousness) should also be noted. However, it has been with the more recent SSI (Socio-Scientific Issues) approach that environmental issues are seriously treated in the context of science education, thus providing more opportunities for the achievement of goals concerning the natural environment in general (Hadzigeorgiou \& Skoumios, 2013).

Indeed the SSI approach appears to be more promising, compared with the traditional STS approach, in the sense that it offers more opportunities for raising environmental awareness. The reason is that the SSI approach focuses on empowering students to reflect upon the interrelationship between the physical and the social world, and their own life, and also upon the moral principles that guide their decision-making in regard to socio-scientific issues (Dolan, Nichols, \& Zeidler, 2009; Sadler \& Zeidler, 2005; Zeidler, Sadler, Simmons, \& Howes, 2005; Zeidler \& Nichols, 2009; Wals, 2011; Walker \& Zeidler, 2007). But what about physical science per se? Can the teaching and learning of physical science concepts and principles help raise environmental awareness? These are important questions because, on the one hand, the school science curriculum is not limited to socio-scientific issues, and on the other hand, traditional school science education is hostile to approaching environmental issues in general, due to modelling and the empirical treatment of the natural world (see Hadzigeorgiou \& Skoumios, 2013). It is for these reasons that aesthetics should be seriously considered when approaching the natural world, especially in the context of school science education.

Given that environmental awareness is directly linked to environmental knowledge, attitudes, and actions or to knowledge of the interrelationships between issues/problems and human life (Hadzigeorgiou \& Skoumios, 2013), the SSI approach, according to what was said above, appears to be more appropriate in the case in which the development of environmental awareness is an educational goal. However, science ideas can also help raise environmental awareness. The aesthetic appreciation of the natural world can play a crucially important role toward that end, provided the natural world becomes students' object of study, as will be discussed in this paper, and the relationship between science and aesthetics is seriously considered.

\section{Beauty and Aesthetics in Science}

The view that art and science share a common aesthetic element has been stressed by various scientists (see Tauber, 1996). In fact, the notion of "synaesthesis" as the "simultaneous, harmonious experience of diverse sensory impressions from complex works of art resulting in a fusion of apparent opposites or in a unification of differences (Richards, Ogden, \& Wood, 1925: p. 7) can be common to artists and scientists alike. Even though such experience of "synaesthesis" is not very common among people, the fact that its existence has been reported in the literature (Tauber, 1996; see also Lemley, 1999), makes the relationship between beauty and science worth exploring and worth keeping in mind, especially when designing science curriculum and instruction. Given the power of art and aesthetics to engage students in science, the connection of science and beauty is crucially important in the context of science education, especially, as will be discussed in this paper, if raising environmental awareness is a goal.

Beauty can be associated with wholeness (see section on the experience of wonder through the perception of beauty), and can indeed be experienced during one's appreciation of both a scientific theory and a work of art (Bohm, 1988; Root-Bernstein, 1996, 2002). This means that scientific truth is not judged solely on the grounds that scientific ideas correspond to certain observable facts, but also because they contribute to a sense of wholeness (Bohm, 1988). Moreover, at the moment of creation, it has been found that the boundaries between art and 
science cease to exist and aesthetics play a central role (Miller, 2001). What is also important to bear in mind is that with the advent of quantum physics and the theory of relativity, the distinction between art and science became blurred. Not only aesthetics (see Tauber, 1997; Root-Bernstein, 2002) but also symbolic language became central to the creation of scientific knowledge. Werner Heisenberg described Niels Bohr as an artist, who, in using his brushes and various colours, tried to convey, just like an artist, his own images to other scientists.. And Bohr himself did point out that in the new physics, where one studies the behaviour of atoms, language can be used as in poetry (see Hadzigeorgiou, Fokialis, \& Kampouropoulou, 2012).

Miller's (2001) work on the life and work of Einstein and Picasso reveals parallels between the two men, and provides an insight into how the shift from positivism influenced both art and science. For the distinctions between the visible and the invisible, the distant and the near became blurred, and the unification of time and space, the idea of simultaneity and that no two observers see exactly the same thing, were ideas that were common in both art and science. The similarities between cubism and the theory of relativity is evidence, according to Miller's (2001) analysis, of those common ideas. Moreover, the creation of mental imagery and analogies, used by both artists and scientists, points to the crucial role of imagination in both artistic and scientific creativity.

In light of the above, it would be misleading to reduce the aesthetic element of science solely to mathematical abstraction (e.g., symmetrical equations, simplified mathematical models). The aesthetic element inherent in the variety of natural phenomena can be used by science educators and science teachers to raise aesthetic awareness, regardless of the concept to be taught, provided, of course, that the target concept is illustrated by, or explains. the perceived phenomenon (see section on implications).

\section{Aesthetics as a Form of Awareness}

In light of the delicate distinction between school learning in general and awareness or 'conscious learning' in particular, aesthetics, as a means to raise environmental awareness, is quite legitimate. Even though this possibility is not new-indeed the relationship between the field of environmental aesthetics (see Shapshay, 2013) and environmentalism has been recently explored by a number of scholars (see Brady, 2009; Carlson, 2010)_, in the field of education the idea of aesthetics has not received the attention it deserves, especially in regard to the natural environment. And in science education, notwithstanding the opportunities for students to approach science learning through the arts, the aesthetic appreciation of nature has not been a mainstream idea. But how can aesthetics be a form of awareness? To answer such a question, one has to consider what the educational philosopher Maxine Greene has called "shock of awareness".

According to her, we do not live "consciously" and it is for this reason that we need to experience those "shocks". She argued that,

A great part of our everyday life is not lived consciously, and since nothing makes an impression, the world seems bland, muffled, and vague. Now and then, however, there are exceptional moments, moments of response to "shocks of awareness". (Greene, 1978: p. 185)

It is after those shocks, according to Greene, that one perceives abruptly something and sees connections that were not seen before. For many students the world of science and education in general may very well appear bland, muffled, and even vague. And there may be students who have learned science but are not really conscious of what they have learned.

The aesthetic appreciation of the natural world can provide "shocks of awareness" through the experience of a sense of wonder. And, in turn, this experience of wonder can contribute to an "aesthetic awareness". Such aesthetic awareness does not simply have the potential to "quicken us from the slackness of everyday life", as Dewey (1934) said; it is necessary, as will be discussed in the next sections of this paper, for raising environmental awareness. In fact, "aesthetic awareness" can even induce in students a change of outlook on the natural world, something that is considered an important learning outcome. Indeed, the view that learning should be directly related to a change of outlook, to the ability to perceive the world in an unhabitual way has been stressed by both philosophers of education (e.g., Peters, 1973: p. 20) and educators (e.g., Jardine, Clifford, \& Friesen, 2003: p. 102; Schank, 2004).

\section{The Experience of Wonder through the Perception of Beauty}

In making a delicate distinction between curiosity, as the drive to investigate or study something, and wonder, as 
a state of mind or feeling, one has to consider the aesthetic dimension of the latter. This aesthetic dimension includes astonishment and admiration, as both a conceptual analysis of wonder and empirical evidence suggest (Hadzigeorgiou, 2012, 2014; Hadzigeorgiou, Kodakos, \& Garganourakis, 2010). Given that during the state of astonishment "the mind is so entirely filled with its object that it cannot entertain any other" (Burke, 1990: p. 53), a sense of wonder can help develop awareness of the significance of the object of perception. Moreover, it can help counter what curiosity does, along with the empirical treatment of nature, to which it leads, namely, to take things apart, in order to investigate them closely, and thus lose the "bigger picture" of the natural world (Hadzigeorgiou, 2005). This is not to say that curiosity is not important, but only to stress the fact curiosity is directly associated with an analytic approach to the study of nature. In sharp contrast to such an analytic approach, the experience of a sense of wonder is associated with a holistic approach to nature.

Taylor (1998), in associating admiration with wonder, talks of the "poetic" nature of the latter. For Taylor (1998) the emotional response to what is being perceived stems primarily from the wholeness of the object of perception. While curiosity, according to him, is a scientific impulse that strives to dominate nature,

Wonder is poetic and is content to view things in their wholeness and full context [...] When a flower is taken apart and examined as pistil, stamen, stem and petals, each part is seen exactly and a certain curiosity is satisfied; however, curiosity is not wonder, the former being the itch to take apart, the latter to gaze on things as they are. (Taylor, 1998: p. 169)

While acknowledging the crucial importance of curiosity and the empirical treatment to which it leads, and also the importance of modeling in school science education, the importance of wonder evoked by the students' object of study should also be acknowledged. Starting the teaching-learning process not with a hands-on activity, or with some technological applications, but from natural phenomena as the real sources of wonder, is quite crucial. Granted that, in the context of science education, the natural world is directly or indirectly linked to our object of study, a sense of wonder about the natural world can help students become aware of the beauty of natural phenomena and natural objects or entities. For example, instead of giving batteries, wires, and light bulbs in order to introduce concepts and ideas from current electricity, the teacher can evoke a sense of wonder by encouraging students, and especially young children, to observe spectacular natural phenomena (e.g., on video students can watch lightning), by helping them become aware that phenomena can be sources of aesthetic beauty.

In distinguishing between "knowing", as a moment of awareness, in which contact occurs between the knower and the known - the contact being "nonconceptual, nonimaginal, nondiscursive, and extremely brief”-and "having knowledge," as a state consisting of "descriptive or interpretive claims to the effect that such-and-such is the case” (Pihakka, 1997, cited in Richards, 2001: p. 66), one can more readily appreciate the role wonder can play in fostering environmental awareness.

There is, of course, a question in regard to the possibilities students have for experiencing a sense of wonder through an awareness of beauty of quite familiar phenomena (e.g., rain, snow, photosynthesis) and entities of the natural world (e.g., a leaf, a tree, a rock). However, what should be noted is that wonder can be evoked through simple, ordinary and familiar situations, thus making one see something usual and ordinary as unusual and extraordinary. Martin Heidegger, in fact, in distinguishing between curiosity and wonder, had pointed that out:

Unlike curiosity which presupposes that there is a distinction between the usual and the unusual, ordinary and extraordinary, wonder is an attunement in which one finds the usual to be extraordinary. (Stone, 2006: p. 208)

In this sense, wonder can be evoked even through the most familiar natural phenomena (e.g., rain, snow), that are neither spectacular like lightning or sea waves, nor unfamiliar like aurora borealis or stellar explosions. New technologies can indeed be helpful by revealing the beauty, for example, of a water drop and a snowflake; the beauty of an ordinary leaf and a table-salt crystal. And such natural entities can become objects of aesthetic appreciation. The next section deals specifically with how the natural world can be appreciated aesthetically.

\section{The Aesthetic Appreciation of the Natural World}

Providing young students with opportunities to appreciate the beauty of the natural environment through direct experiences is crucial not just for the development of an emotional bond with it, but for the development of students' sense of place. According to environmental psychology literature, children's sense of place is affected by 
a number of factors, including aesthetic factors (Bechtel \& Churchmen, 2002). There is also evidence that, in addition to prior exposure to different environments, vicarious familiarity with diverse environments through the media may also affect young students’ choice and evaluation of favorite places (Korpela, 2002). An aesthetic, therefore, appreciation of the natural world, through a vicarious experience, especially through the experience of a sense of wonder, may very well encourage environmental awareness, by affecting, at the same time, children's choice of favorite places in nature. One, of course, could argue that an aesthetic appreciation of the natural world is not environmental awareness. Yet the experience of a sense of wonder, evoked through such an aesthetic appreciation, can foster environmental awareness by raising awareness of the beauty of the natural world. How is this possible?

Natural beauty, as Richards (2001) argues, has an adaptive value since it may advance a greater connection with the natural world. Although this could also be contested, there is a pressing and legitimate question: why do we respond so quickly and intensely to certain images of the natural world? Why do natural forms around us (i.e., mountains, forests, clouds, trees, waterfalls, flashes of lightning) capture our attention, evoke appreciation, and inspire even awe? Fractals forms in particular, found in these natural forms, can be associated with transcendent experiences of beauty, even with the sublime (see Santayana, 1955). It makes therefore sense to talk about "a transcendent reaction of our deeply aware ecological self (Richards, 2001: p. 63), and about beauty leading to “a deeper holistic awareness” (Richards, 2001: p. 66). This "holistic awareness” also echoes Whitehead's (1933) view that beauty and awareness are linked in a complex network of relationships between the various components of reality.

Beauty concerns the inter-relations of the various components of reality, the inter-relations of the various components of Appearance, and also the relations of Appearance to Reality. (p. 341)

Because Richards' (2001) idea of “holistic awareness” includes cognitive, affective, aesthetic, and even ethical factors, the possibility of raising environmental awareness through the complex interplay of aesthetic and ethical factors deserves particular attention. In actual fact, the relationship between aesthetic and moral value, and by extension, the relationship between aesthetic and moral/ethical judgement (Blum, 1994; Irvin, 2008; Muelder-Eaton, 1999), makes the aesthetic appreciation of nature an idea that can guide learning activities aiming to develop environmental awareness through moral/ethical judgement.

Indeed, if aesthetic experiences range from negative to positive and ethical reasoning or conduct range from bad or wrong to/good or right, there are many possible combinations resulting from the relationship between aesthetics and ethics. The ideal, of course, situation would be one that leads to an experience that is both extremely pleasing to the senses and extremely positive from an ethical point of view. However, situations or actions, which are both displeasing and unethical (i.e., polluting the natural environment, exploiting/wasting natural resources) both displease the senses and are ethically deplorable and unacceptable. Certainly there are many ethical actions, which require altruism, even sacrifice, but which are not aesthetic at all (i.e., risking one's life to save the natural environment).

\section{Implications for Science Education}

What are the implications of the above for science education? The aesthetic appreciation of the natural world is in line with a "romantic" approach to science education, but which was abandoned (see Bossi \& Poggi, 1994; Hadzigeorgiou \& Schulz, 2014). Although such a "romantic" approach is not the "standard” approach to teaching and learning science nowadays, it can nevertheless be incorporated in most teaching/learning models, provided that time is given to students to perceive aesthetic beauty in natural phenomena. Given that most such phenomena have an aesthetic dimension, the curricular question concerns whether the natural world itself is presented to the students (Hadzigeorgiou \& Schulz, 2014).

Of course, one could ask: What about concepts such as, for example, force, energy, momentum, electric charge, sound? This is a crucially important question, given that these are the very concepts of science, but which are just abstract concepts. How can one perceive beauty in the concepts, for example, of force and energy? The answer is that we need situations in which these concepts are embedded (e.g., the motion of clouds, the motion of sea waves, a volcano, a tornado, the water cycle, a flash of lightning). In other words, we need to select phenomena and situations, which 'aesthetically' exemplify the concepts to be introduced. And because, as was previously discussed, a sense of wonder, evoked through an aesthetic appreciation of the natural world, can help 
students become aware of the significance of the object of perception, awareness of the significance of science concepts ideas can also be raised, provided that the latter are embedded in the object of perception (Hadzigeorgiou \& Schulz, 2014). On the other hand, in the case of certain concepts (e.g., energy, the water cycle), we can select situations (e.g., energy production, water consumption), which facilitate the raising of aesthetic awareness along with the ethical values associated with these concepts and such awareness. In both cases, the students are provided with opportunities to develop their environmental awareness.

An argument, of course, about associating natural phenomena and non-living entities with ethical/moral reasoning can be raised, since such reasoning goes against Aristotelian, Kantian, and utilitarian ethics. As Sorell (2000) points out, such kind of ethics constitute an anomaly for moral theory. However, in line with a holistic/ ecological perspective (Doll, 1993; Slattery, 1995; Slattery \& Rapp, 2003), the inclusion of non-living entities is imperative.

If aesthetics and ethics are both about love, about "a caring for the other", about a "let-it-be-for-the-other" attitude, as Murdoch (1959) argues, then the aesthetic appreciation of Nature, through an appreciation of the beauty of natural phenomena (through direct or vicarious experience), can provide students with opportunities to develop environmental awareness even when the instructional aim is the learning of an abstract science concept (i.e., energy, momentum).

With regard, of course, the implication of the aesthetic appreciation of the natural world, it should be pointed out that even if the experience of the sublime may be considered unrealistic, the perception of the beauty of natural entities and phenomena is indeed a possibility in the context of science education. True criticisms of the "scenery model" point to the extent to which aesthetic appreciation and valuing can reach beyond mere visual enjoyment to encompass not only the senses and the emotions, but also knowledge imagination (see Brady, 2009). But such criticisms do not exclude the possibilities that were discussed here.

It should be noted that the 2012 NASA "The Earth as Art" collection, consisting of images of the planet taken from observation satellites over the last 40 years, as well as images from several environmental satellites, is based upon the idea that aesthetic appreciation can help raise awareness, by presenting the diversity and beauty of the planet, and also by revealing features and patterns, which are not visible to the naked eye. Such "artistic" images of the Earth can provide excellent material to focus on in order to introduce students to natural phenomena (e.g., erosion caused rivers, volcanic eruptions).

\section{Conclusion}

The urgency of integrating environmental education into the whole system of formal education, and also across the school curriculum, cannot compensate for lack of strategies that help raise environmental awareness. Despite difficulties and problems, some possibilities, especially within science education, for fostering environmental awareness exist (see Littledyke, 1996, 2008), and there may be some others (Hadzigeorgiou \& Skoumios, 2013). One of those possibilities, according to this paper, refers to the aesthetic appreciation of the natural world. Such aesthetic appreciation, especially through an "aesthetic awareness", can even contribute to students' change of outlook, that is, a crucially important educational goal. For as British educational philosopher R.S. Peters (1973) argued, "To be educated is not to have arrived at a destination; it is to travel with a different view" (p. 20). It is high time we thought about the possibility of such a "different view" in the context of science education and education in general. The aesthetic appreciation of the natural world can indeed provide such a possibility.

\section{References}

Bechtel, R., \& Churchman, A. (Eds.) (2002). Handbook of Environmental Psychology. New York: Wiley \& Sons.

Blum, L. (1994). Moral Perception and Particularity. New York: Cambridge University Press. http://dx.doi.org/10.1017/CBO9780511624605

Bohm, D. (1998). On Creativity. London: Routledge.

Bossi, M., \& Poggii, S. (Eds.) (1994). Romanticism in Science. Science in Europe, 1790-1840. Boston, MA: Kluwer.

Brady, E. (2009). Environmental Aesthetics. In J. Callicott, \& R. Frodeman (Eds.), Encyclopedia of Environmental Ethics and Philosophy. Vol. 1 (pp. 313-321). Detroit, MI: Macmillan Reference USA.

Burke, E. (1990). A Philosophical Enquiry into the Origin of Our Ideas. New York: Oxford University Press.

Carlson, A. (2010). Contemporary Environmental Aesthetics and the Requirements of Environmentalism. Environmental Values, 19, 298-314. http://dx.doi.org/10.3197/096327110X519844 
Dewey, J. (1934). Art as Experience. New York: Perigee Books.

Dolan, T., Nichols, B., \& Zeidler, D. (2009). Using Socio-Scientific Issues in Primary Classrooms. Journal of Elementary Science Education, 21, 1-12. http://dx.doi.org/10.1007/BF03174719

Doll, W. (1993). A Post-Modern Perspective on Curriculum. New York: Teachers College Press.

Fisher, P. (1999). Wonder, the Rainbow, and the Aesthetics of Rare Experiences. Cambridge, MA: Harvard University Press.

Greene, M. (1978). Landscapes of Learning. New York: Teachers College Press.

Hadzigeorgiou, Y. (2005). Romantic Understanding and Science Education. Teaching Education, 16, $23-32$. http://dx.doi.org/10.1080/1047621052000341590

Hadzigeorgiou, Y. (2012). Fostering a Sense of Wonder in the Science Classroom. Research in Science Education, 42, 9851005. http://dx.doi.org/10.1007/s11165-011-9225-6

Hadzigeorgiou, Y. (2014). Reclaiming the Value of Wonder in Science Education. In K. Egan, A. Cant, \& G. Judson (Eds.), "Wonder-Full Education": The Centrality of Wonder in Teaching and Learning across the Curriculum (pp. 60-84). New York and London: Routledge.

Hadzigeorgiou, Y., \& Garganourakis, V. (2010). Using Nikola Tesla’s Story and His Experiments as Presented in the Film “The Prestige” to Promote Scientific Inquiry: A Report of an Action Research Project. Interchange, 41, 363-378. http://dx.doi.org/10.1007/s10780-010-9136-X

Hadzigeorgiou, Y., Fokiali, P., \& Kampouropoulou, M. (2012). Thinking about Creativity in Science Education. Creative Education, 3, 603-611. http://dx.doi.org/10.4236/ce.2012.35089

Hadzigeorgiou, Y., \& Skoumios, M. (2013). The Development of Environmental Awareness through School Science: Problems and Possibilities. International Journal of Environmental \& Science Education, 8, 405-426.

Hadzigeorgiou, Y., \& Schulz, R. (2014). Romanticism and Romantic Science: Their Contribution to Science Education. Science \& Education, 23, 1963-2006. http://dx.doi.org/10.1007/s11191-014-9711-0

Irvin, S. (2008). The Pervasiveness of the Aesthetic in Everyday Experience. British Journal of Aesthetics, 48, 29-44. http://dx.doi.org/10.1093/aesthj/aym039

Jardine, D., Clifford, P., \& Friesen, S. (2003). Back to the Basics of Teaching and Learning. Mahwah, NJ: Lawrence Erlbaum.

Kuhn, T. (1970). The Structure of Scientific Revolutions. Chicago, IL: University of Chicago Press.

Korpela, K. (2002). Children’s Environment. In R. Bechtel, \& A. Churchman (Eds.), Handbook of Environmental Psychology (pp. 363-373). New York: Wiley \& Sons.

Littledyke, M. (1996). Science Education for Environmental Awareness in a Postmodern World. Environmental Education Research, 2, 197-214. http://dx.doi.org/10.1080/1350462960020206

Littledyke, M. (2008). Science Education for Environmental Awareness: Approaches to Integrating Cognitive and Affective Domains. Environmental Education Research, 14, 1-7. http://dx.doi.org/10.1080/13504620701843301

Lemley, B. (1999). Do You See What They See? Discover, 20, 80-87.

Miller, A. (2001). Einstein, Picasso: Space, Time, and the Beauty That Causes Havoc. New York: Basic Books.

Muelder-Eaton, M. (1999). Basic Issues in Aesthetics. Prospect Heights, IL: Waveland Press.

Murdoch, I. (1959). The Sublime and the Good. Chicago Review, 13, 42-45. http://dx.doi.org/10.2307/25293537

Peters, R. (1973). Aims of Education: A Conceptual Enquiry. In R. Peters (Ed.), The Philosophy of Education (pp. 1-35). Oxford: Oxford University Press.

Richards, I., Ogden, C., \& Wood, J. (1925). The Foundations of Aesthetics. New York: International Publishers.

Richards, R. (2001). A New Aesthetic for Environmental Awareness: Chaos Theory, the Beauty of Nature, and Our Broader Humanistic Identity. Journal of Humanistic Psychology, 41, 59-95. http://dx.doi.org/10.1177/0022167801412006

Root-Bernstein, R. S. (1996). The Sciences and Arts Share a Common Creative Aesthetic. In A. Tauber (Ed.), The Elusive Synthesis: Aesthetics and Science (pp. 49-82). Boston, MA and London: Kluwer.

http://dx.doi.org/10.1007/978-94-009-1786-6 3

Root-Bernstein, R. S. (2002). Aesthetic Cognition. International Studies in Philosophy of Science, 16, 61-77. http://dx.doi.org/10.1080/02698590120118837

Sadler, T. D., \& Zeidler, D. L. (2005). Patterns of Informal Reasoning in the Context of Socioscientific Decision Making. Journal of Research in Science Teaching, 42, 112-138. http://dx.doi.org/10.1002/tea.20042

Santayana, G. (1955). The Sense of Beauty: Being the Outline of an Aesthetic Theory. New York: Dover.

Schank, R. (2004). Making Minds Less Well Educated than Our Own. Mahwah, NJ: Lawrence Erlbaum. 
Shapshay, S. (2013). Contemporary Environmental Aesthetics and the Neglect of the Sublime. British Journal of Aesthetics, 53, 181-198. http://dx.doi.org/10.1093/aesthj/ays067

Slattery, P. (1995). Curriculum Development in the Postmodern Era. New York: Garland.

Slattery, P., \& Rapp, D. (2003). Ethics and the Foundation of Education. Boston, MA: Allyn \& Bacon.

Sorell, T. (2000). Moral Theory and Anomaly. Oxford: Basil Blackwell.

Stone, B. E. (2006). Curiosity as the Thief of Wonder: An Essay on Heidegger's Critique of the Ordinary Conception of Time. Kronoscope, 6, 205-229. http://dx.doi.org/10.1163/156852406779751881

Tauber, A. I. (1996). The Elusive Synthesis: Science and Aesthetics. Boston, MA and London: Kluwer. http://dx.doi.org/10.1007/978-94-009-1786-6

Taylor, J. (1998). Poetic Knowledge: The Recovery of Education. New York: SUNY Press.

Walker, K. A., \& Zeidler, D. L. (2007). Promoting Discourse about Socioscientific Issues through Scaffolded Inquiry. International Journal of Science Education, 29, 1387-1410. http://dx.doi.org/10.1080/09500690601068095

Wals, A. E. J. (2011). Learning Our Way to Sustainability. Journal of Education for Sustainable Development, 5, $177-186$. http://dx.doi.org/10.1177/097340821100500208

Whitehead, A. (1933). Adventure of Ideas. New York: McMillan.

Zeidler, D. L., \& Nichols, B. H. (2009). Socioscientific Issues: Theory and Practice. Journal of Elementary Science Education, 21, 49-58. http://dx.doi.org/10.1007/BF03173684

Zeidler, D. L., Sadler, T. D., Simmons, M. L., \& Howes, E. V. (2005). Beyond STS: A Research-Based Framework for Socioscientific Issues Education. Science Education, 89, 357-377. http://dx.doi.org/10.1002/sce.20048 